\title{
Quota Restrictions and Intra-Firm Reallocations: Evidence from Chinese Exports to the US
}

\author{
Richard Upward* \\ Zheng $\mathrm{Wang}^{\dagger}$ \\ University of Nottingham \\ University of Hull
}

March 13, 2016

\begin{abstract}
We study how Chinese textile and clothing firms adjusted the product structure of their exports to the US, as triggered by the termination of Multifiber Arrangement (MFA) quotas. We find that the removal of MFA quotas induced firms to expand their product scope while reducing the concentration on their core product. These effects are strong for domestic and foreign privately-owned firms, but insignificant for state-owned firms.

Highlights: $>$ Quota removal induces firms to export new products. Quota removal induces firms to shift resources away from their core products. State-owned firms are less affected by the quota removal than their private counterparts.
\end{abstract}

Key Words: Quota; MFA; Textile; Product scope; Product concentration

JEL Classifications: D22, F13, L67

\footnotetext{
${ }^{*}$ School of Economics, University of Nottingham and Nottingham Centre for Research on Globalisation and Economic Policy.

${ }^{\dagger}$ Corresponding author. Hull University Business School and Nottingham Centre for Research on Globalisation and Economic Policy. Email: z.wang@hull.ac.uk
} 


\section{Introduction}

It is well-known both theoretically and empirically that import quotas lead to higher quality products being exported (e.g. Feenstra, 1988; Harrigan and Barrows, 2009; Khandelwal et al., 2013). However, it is not yet clear how quotas affect the reallocation of resources across export products within firms. This paper provides evidence on this question by showing how Chinese firms adjust the scope and concentration of their textile and clothing products exported to the US market following the abrupt termination of the Multifiber Arrangement (MFA) quotas in 2015.

Our research is closely linked to the recent literature on multi-product firms, which highlights firms' product-mix adjustments in response to trade liberalization (e.g. Arkolakis et al., 2015; Baldwin and Gu, 2009; Bernard et al., 2010, 2011; Eckel and Neary, 2010; Goldberg et al., 2010; Iacovone and Javorcik, 2010; Mayer et al., 2014; Qiu and Zhou, 2013). A common feature of these studies is that firms reorganize the scope and concentration of their export products under specific market conditions. To the extent that the effect of a quota is equivalent to an increase per (physical) unit cost (Demidova et al., 2009; Falvey, 1979; Feenstra, 2003; Khandelwal et al., 2013), the end of the MFA presents a clear-cut, exogenous, and discrete episode of trade liberalization which allows us to identify within-firm adjustments following an abrupt removal of a specific type of trade barrier.

\section{Data and Research Design}

Our data on Chinese exports to the US come from a transaction-level database provided by Chinese Customs, spanning 2002-2006. Quota products (HS8 level) are identified using the list provided by China Chamber of Commerce for Import and Export of Textiles (2002). Established in 1994, the MFA enables developed countries (including the US) to set quantity caps on textile and clothing imports from developing countries; see 
Khandelwal et al. (2013) for more details of this trade data and the policy background of the MFA. The MFA quotas remained in place until January 1st 2005, at which point all quantity caps were dismantled.

The clear timing of the quota removal and the variation in the extent to which firms were constrained by the quotas allow us to use a Difference-in-Differences (DiD) framework to identify the effect of the MFA quota elimination. The DiD regression takes the following form:

$$
y_{i t}=\alpha+\mathbf{T}_{t}^{\prime} \boldsymbol{\beta}+\mathbf{T D}_{i t}^{\prime} \boldsymbol{\delta}+\theta_{i}+\varepsilon_{i t},
$$

where $i$ and $t$ index firm and year; $y_{i t}$ is the outcome variable, namely the number of export products or the concentration of export products; $\alpha$ is the constant term; $\mathbf{T}_{t}$ is a vector containing year dummies with the omitted year being $2002 ; \mathbf{T D}_{i t}$ contains all interactions between the elements of $\mathbf{T}_{t}$ and indicators of comparison groups $\mathbf{D}_{i} ; \theta_{i}$ is a firm fixed effect $;^{1} \varepsilon_{i t}$ is a zero mean error term assumed to be uncorrelated with the covariates; all other parameters are coefficients to be estimated. The key coefficients of interest are in the vector $\boldsymbol{\delta}$, which captures how the differences between firms varies across years. In particular, $\delta_{2005}$ and $\delta_{2006}$ capture the DiD estimate of the effect of quota removal on firms' product scope and concentration for the years immediately following quota removal. In addition, $\delta_{2003}$ and $\delta_{2004}$ capture any pre-quota removal effect relative to the base year.

\section{Results}

For the main part of the analysis, we define export product scope as the number of products exported (at the HS8 level), and we define export product concentration as the share of the top product in export value, as in Bernard et al. (2011). We restrict the sample to pure textile and clothing firms, defined as those who exported only textile and

\footnotetext{
${ }^{1}$ Note that the inclusion of firm fixed effects absorbs the main effects of group indicators $\mathbf{D}_{i t}$.
} 
Table 1. Chinese textile and clothing exporters to the US

\begin{tabular}{rrrrrrrrrrr}
\hline & \multicolumn{3}{c}{ Number of firms } & & \multicolumn{3}{c}{ Share of export value \% } \\
\cline { 2 - 4 } \cline { 7 - 9 } Year & Mixed & Quota & $\begin{array}{c}\text { Non- } \\
\text { quota }\end{array}$ & Total & & Mixed & Quota & $\begin{array}{r}\text { Non- } \\
\text { quota }\end{array}$ & Total \\
\hline 2002 & 573 & 415 & 403 & 1,391 & & 67.2 & 19.2 & 13.7 & 100 \\
2003 & 811 & 498 & 526 & 1,835 & & 70.4 & 15.2 & 14.4 & 100 \\
2004 & 1,093 & 656 & 697 & 2,446 & & 71.8 & 14.3 & 13.9 & 100 \\
2005 & 1,970 & 3,071 & 960 & 6,001 & & 61.7 & 28.9 & 9.4 & 100 \\
2006 & 2,003 & 3,425 & 1,196 & 6,624 & & 58.5 & 29.8 & 11.7 & 100 \\
\hline
\end{tabular}

Notes: "Mixed" refers to firms who exported both quota and non-quota textile and clothing products at least once in the sample period, "Quota" refers to firms who exported only quota-constrained textile and clothing products in all years, and "Non-quota" refers to firms who exported only non-quota textile and clothing products in all years. Textile and clothing products are those products included in the Harmonized System (HS) chapters 50-63.

clothing products to the US. Products may be "quota" or "non-quota", meaning that they were subject to quota restrictions for export to the US in $2004 .^{2}$ The sample is split into three comparison groups:

1. Firms who exported quota and non-quota products to the US ("Mixed");

2. Firms who exported only quota products to the US ("Quota");

3. Firms who exported only non-quota products to the US ("Non-quota").

Non-quota firms are a natural control group. Table 1 contains summary statistics for this sample. It is shown that mixed firms made up the largest part of the sample both in terms of numbers of firm and in terms of the value of exports before 2005, but after the quota removal they were significantly outnumbered by quota firms due to the influx of relatively smaller firms selling previously quota-constrained products to the US. We include firm fixed effects throughout our DiD estimations to control for the influence of the changes in the composition of the firms.

\footnotetext{
${ }^{2}$ Here we do not consider whether quotas are binding or not, because a "binding quota" is a concept that applies in aggregate. When individual firms apply for a quota, especially in the Chinese context, whether the quota is binding at the country level is not necessarily relevant to them. State firms are less bound by quotas, and private firms more likely to be bound by quotas, even if the quotas are binding at the country level; see Yang (1999) and (Moore, 2002, Ch. 5) for more details on the MFA quota allocation system in China.
} 
Table 2. The effect of quota removal: comparison of quota and non-quota firms

\begin{tabular}{|c|c|c|c|c|c|c|c|c|}
\hline & \multicolumn{4}{|c|}{ Product scope } & \multicolumn{4}{|c|}{ Product concentration } \\
\hline & (1) & (2) & (3) & (4) & (5) & (6) & (7) & (8) \\
\hline & All firms & $\begin{array}{l}\text { Private } \\
\text { domestic }\end{array}$ & $\begin{array}{l}\text { State- } \\
\text { owned }\end{array}$ & $\begin{array}{l}\text { Foreign- } \\
\text { owned }\end{array}$ & All firms & $\begin{array}{l}\text { Private } \\
\text { domestic }\end{array}$ & $\begin{array}{l}\text { State- } \\
\text { owned }\end{array}$ & $\begin{array}{l}\text { Foreign- } \\
\text { owned }\end{array}$ \\
\hline$\delta_{2003}$ & $\begin{array}{r}-0.065 \\
(0.365)\end{array}$ & $\begin{array}{c}-0.104 \\
(0.441)\end{array}$ & $\begin{array}{c}0.557 \\
(0.860)\end{array}$ & $\begin{array}{c}-0.162 \\
(0.881)\end{array}$ & $\begin{array}{c}0.005 \\
(0.022)\end{array}$ & $\begin{array}{c}0.009 \\
(0.028)\end{array}$ & $\begin{array}{c}-0.112 \\
(0.072)\end{array}$ & $\begin{array}{c}0.029 \\
(0.047)\end{array}$ \\
\hline$\delta_{2004}$ & $\begin{array}{c}-0.173 \\
(0.373)\end{array}$ & $\begin{array}{c}-0.238 \\
(0.451)\end{array}$ & $\begin{array}{c}0.953 \\
(0.919)\end{array}$ & $\begin{array}{c}-0.262 \\
(0.875)\end{array}$ & $\begin{array}{c}0.018 \\
(0.022)\end{array}$ & $\begin{array}{c}0.039 \\
(0.028)\end{array}$ & $\begin{array}{r}-0.135^{*} \\
(0.077)\end{array}$ & $\begin{array}{c}0.005 \\
(0.046)\end{array}$ \\
\hline$\delta_{2005}$ & $\begin{array}{l}1.154^{* * *} \\
(0.368)\end{array}$ & $\begin{array}{c}0.948^{* *} \\
(0.446)\end{array}$ & $\begin{array}{c}0.998 \\
(0.987)\end{array}$ & $\begin{array}{c}1.976^{* *} \\
(0.841)\end{array}$ & $\begin{array}{c}-0.084^{* * *} \\
(0.022)\end{array}$ & $\begin{array}{c}-0.055^{* *} \\
(0.028)\end{array}$ & $\begin{array}{c}-0.206^{* *} \\
(0.083)\end{array}$ & $\begin{array}{c}-0.136^{* * *} \\
(0.044)\end{array}$ \\
\hline$\delta_{2006}$ & $\begin{array}{l}1.077^{* * *} \\
(0.376)\end{array}$ & $\begin{array}{c}0.939^{* *} \\
(0.455)\end{array}$ & $\begin{array}{r}-0.088 \\
(1.023)\end{array}$ & $\begin{array}{c}1.856^{* *} \\
(0.857)\end{array}$ & $\begin{array}{c}-0.070^{* * *} \\
(0.023)\end{array}$ & $\begin{array}{c}-0.046 \\
(0.028)\end{array}$ & $\begin{array}{c}-0.135 \\
(0.086)\end{array}$ & $\begin{array}{c}-0.116^{* *} \\
(0.045)\end{array}$ \\
\hline$N$ & 18,297 & 12,648 & 828 & 4,821 & 18,297 & 12,648 & 828 & 4,821 \\
\hline$R^{2}$ & 0.780 & 0.772 & 0.776 & 0.798 & 0.744 & 0.735 & 0.678 & 0.777 \\
\hline
\end{tabular}

Notes: table reports estimates of the elements of $\boldsymbol{\delta}$ from (1). Product scope is measured as the number of products, and product concentration the highest share of a single product in a firm's exports. The DiD comparison is between quota firms and non-quota firms. Firm fixed effects are included in all regressions. Standard errors are in parentheses; ${ }^{*},{ }^{* *},{ }^{* *}$ indicate significance at $10 \%, 5 \%$, and $1 \%$ levels respectively.

Column (1) of Table 2 presents our baseline results for the effects of quota removal on product scope, in which we compare quota firms with non-quota firms. Product scope does not diverge between these two groups of firms before 2005 (estimates of $\delta_{2003}$ and $\delta_{2004}$ are not significantly different from zero). But in 2005, product scope expands significantly more in quota firms (by about 1.2 products), and this difference remains in 2006. Column (5) shows the same comparison for for product concentration. The average share of the top product shows no divergence between quota and nonquota firms before 2005, but concentration falls significantly more in quota firms from 2005 onwards. These findings provide clear and consistent evidence that the removal of quotas induces significant readjustments within firms: exporters tend to diversify their export portfolios by expanding their product scope and by more evenly spreading out their resources across export products, which accords with the prediction of some recent theories about the effects of reduced trade costs on multi-product firms (e.g. Bernard et al., 2011). 
The remaining columns of Table 2 shows how this effect varies across different firm ownership types. Comparing $\delta_{2005}$ with $\delta_{2004}$, it can be seen that the increase in product scope is largest for foreign-owned firms. The decrease in product concentration is also larger for foreign-owned than private domestic firms. Estimates of the response of stateowned firms are imprecise, but it is clear that there is no sudden increase in product scope after 2005, and in 2006 the DiD estimate is close to zero for state-owned firms. There is some evidence of a reduction in concentration for state-owned firms, but again the timing of this change is not consistent with the timing of the quota removal.

More precise results are obtained when we consider within-firm variations. Specifically, the existence of mixed firms in the sample (which exported both quota and nonquota products) allows us to identify the quota removal effect by comparing product scope and concentration within firms. In practice, we estimate (1) on the sample of mixed firms only, defining $D_{i}=1$ for quota products and $D_{i}=0$ for non-quota products. Dyadic firm-product fixed effects are included to control for the changes in sample composition and any other unobserved effects at the firm-product level. The results are reported in Table 3. Compared to the cross-firm estimation in Table 2, this estimation exercise shows much stronger effects and much sharper differences across ownership types. In particular, state-owned firms are now consistently less responsive to the lift of quotas than private domestic and foreign-owned firms. For both product scope and product concentration, the size of the estimated effect for state-owned firms is roughly a half or less of the effects for other firms. The relative lack of responsiveness of state-owned firms echoes the existing finding that state-owned firms in China were less constrained by quota restrictions (Khandelwal et al., 2013; Moore, 2002; Yang, 1999), and more importantly it points to the fact inefficient management of quotas by the government could lead to resource misallocation and thus an exogenous removal of quotas could result in "greater-than-expected gains" (Khandelwal et al., 2013). 
Table 3. The effect of quota removal: comparison of quota and non-quota products within firms that export both

\begin{tabular}{|c|c|c|c|c|c|c|c|c|}
\hline & \multicolumn{4}{|c|}{ Product scope } & \multicolumn{4}{|c|}{ Product concentration } \\
\hline & (1) & $(2)$ & $(3)$ & (4) & $(5)$ & $(6)$ & $(7)$ & $(8)$ \\
\hline & All & $\begin{array}{r}\text { Private } \\
\text { domestic }\end{array}$ & $\begin{array}{l}\text { State- } \\
\text { owned }\end{array}$ & $\begin{array}{r}\text { Foreign- } \\
\text { owned }\end{array}$ & All & $\begin{array}{r}\text { Private } \\
\text { domestic }\end{array}$ & $\begin{array}{l}\text { State- } \\
\text { owned }\end{array}$ & $\begin{array}{r}\text { Foreign- } \\
\text { owned }\end{array}$ \\
\hline$\delta_{2003}$ & $\begin{array}{c}0.180 \\
(0.306)\end{array}$ & $\begin{array}{c}0.413 \\
(0.363)\end{array}$ & $\begin{array}{r}-0.641 \\
(0.775)\end{array}$ & $\begin{array}{c}-0.005 \\
(0.677)\end{array}$ & $\begin{array}{r}-0.016 \\
(0.019)\end{array}$ & $\begin{array}{c}-0.033 \\
(0.023)\end{array}$ & $\begin{array}{c}0.060 \\
(0.072)\end{array}$ & $\begin{array}{c}0.015 \\
(0.039)\end{array}$ \\
\hline$\delta_{2004}$ & $\begin{array}{c}0.682^{* *} \\
(0.308)\end{array}$ & $\begin{array}{l}0.952^{* * *} \\
(0.363)\end{array}$ & $\begin{array}{r}-0.559 \\
(0.905)\end{array}$ & $\begin{array}{c}0.581 \\
(0.680)\end{array}$ & $\begin{array}{c}-0.008 \\
(0.019)\end{array}$ & $\begin{array}{c}-0.029 \\
(0.023)\end{array}$ & $\begin{array}{r}-0.037 \\
(0.084)\end{array}$ & $\begin{array}{c}0.049 \\
(0.039)\end{array}$ \\
\hline$\delta_{2005}$ & $\begin{array}{l}3.651^{* * *} \\
(0.299)\end{array}$ & $\begin{array}{l}3.546^{* * *} \\
(0.353)\end{array}$ & $\begin{array}{l}1.697^{*} \\
(0.904)\end{array}$ & $\begin{array}{l}4.901^{* * *} \\
(0.652)\end{array}$ & $\begin{array}{c}-0.124^{* * *} \\
(0.018)\end{array}$ & $\begin{array}{c}-0.134^{* * *} \\
(0.022)\end{array}$ & $\begin{array}{c}-0.061 \\
(0.084)\end{array}$ & $\begin{array}{c}-0.116^{* * *} \\
(0.038)\end{array}$ \\
\hline$\delta_{2006}$ & $\begin{array}{l}3.862^{* * *} \\
(0.306)\end{array}$ & $\begin{array}{l}3.766^{\text {*** }} \\
(0.364)\end{array}$ & $\begin{array}{c}1.498 \\
(0.949)\end{array}$ & $\begin{array}{l}5.146^{* * *} \\
(0.658)\end{array}$ & $\begin{array}{c}-0.124^{* * *} \\
(0.019)\end{array}$ & $\begin{array}{c}-0.138^{* * *} \\
(0.023)\end{array}$ & $\begin{array}{r}-0.086 \\
(0.088)\end{array}$ & $\begin{array}{c}-0.105^{* * *} \\
(0.038)\end{array}$ \\
\hline$N$ & 10,077 & 6,909 & 400 & 2,768 & 10,077 & 6,909 & 400 & 2,768 \\
\hline$R^{2}$ & 0.775 & 0.757 & 0.804 & 0.810 & 0.721 & 0.708 & 0.704 & 0.751 \\
\hline
\end{tabular}

Notes: see notes for Table 2. The DiD comparison is between quota products and non-quota products in mixed firms.

If we exclude single-product firms which exported only one product to the US in 2004, we find the effects on product scope and product concentration to have the same signs as in baseline results, but none remain significantly different from zero, implying a stronger response of single-product exporters than multi-product exporters. If we focus only on the subset of products which firms exported consecutively in 2004 and in 2005, the estimation gives slightly smaller estimates and most of them lose statistical significance, indicating that the baseline findings are largely driven by the net addition of export products.

Our main results are robust to two alternative methods. First, using a Herfindahl index as an alternative product concentration measure, we find the overall effect on Herfindahl index is a decrease of 0.11 (less concentrated), which is significantly different from zero at $5 \%$ level. Second, we can also use the US and Japanese markets for a DiD comparison, by comparing quota firms' exports to the US (as a developed market with MFA quotas before 2005) versus quota firms' exports to Japan (as a developed market without MFA quotas before 2005). This comparison yields larger effects (1.6 for product scope and -0.1 for product concentration), both of which are significant at the $1 \%$ level. 


\section{Conclusions}

Chinese exporters responded to the removal of MFA quotas in the US by adding on average 1.2 new products to their export portfolios and shifting resources towards less important products by lowering the share of the best-selling product by 0.9 percentage points. Domestic and foreign privately owned firms, and firms which exported both quota and non-quota products exhibited larger adjustment. This finding implies that the existence of quotas forces incumbent firms to concentrate more on their products of core competence and thus becoming "leaner and meaner" in the export market. A promising avenue of research would be to theoretically investigate the full effects of quotas in a multi-product firm framework such as Bernard et al. (2011) and Eckel and Neary (2010) and evaluate the welfare implications.

\section{References}

Arkolakis, C., S. Ganapati, and M.-A. Muendler (2015): "The Extensive Margin of Exporting Products: A Firm-level Analysis," Mimeo.

Baldwin, J. And W. Gu (2009): "The Impact of Trade on Plant Scale, ProductionRun Length and Diversification," in Producer Dynamics: New Evidence from Micro Data, ed. by T. Dunne, J. B. Jensen, and M. J. Roberts, University of Chicago Press.

Bernard, A. B., S. J. Redding, and P. K. Schott (2010): "Multi-Product Firms and Product Switching," American Economic Review, 100(1), 70-97.

(2011): "Multi-Product Firms and Trade Liberalization," Quarterly Journal of Economics, 126(3), 1271-1318.

China Chamber of Commerce for Import and Export of Textiles (2002): Quota-Restrained Textiles and HS Catelogue (Revised Version), Beijing: China Chamber of Commerce for Import and Export of Textiles.

Demidova, S., H. L. Kee, and K. Krishna (2009): "Do Trade Policy Differences Induce Sorting? Theory and Evidence from Bangladeshi Apparel Exporters," Working Paper, Pennsylvania State University.

Eckel, C. And J. P. NeARY (2010): "Multi-Product Firms and Flexible Manufacturing in the Global Economy," Review of Economic Studies, 77(1), 188-217. 
Falvey, R. E. (1979): "The Composition of Trade within Import-restricted Product Categories," Journal of Political Economy, 87(5), 1105-1114.

Feenstra, R. C. (1988): "Quality Change under Trade Restraints in Japanese Autos," Quarterly Journal of Economics, 103(1), 131-46.

(2003): Advanced International Trade: Theory and Evidence, Princeton, NJ: Princeton University Press.

Goldberg, P. K., A. Khandelwal, N. Pavcnik, and P. Topalova (2010): "MultiProduct Firms and Product Turnover in the Developing World: Evidence from India," Review of Economics and Statistics, 92(4), 1042-1049.

Harrigan, J. and G. Barrows (2009): "Testing the Theory of Trade Policy: Evidence from the Abrupt End of the Multifiber Arrangement," Review of Economics and Statistics, 91(2), 282-294.

IACOvone, L. AND B. S. JAvorciK (2010): "Multi-product Exporters: Product Churning, Uncertainty and Export Discoveries," Economic Journal, 120(544), 481-499.

Khandelwal, A. K., P. K. Schott, and S.-J. Wei (2013): "Trade Liberalization and Embedded Institutional Reform: Evidence from Chinese Exporters," American Economic Review, 103(6), 2169-95.

Mayer, T., M. J. Melitz, and G. I. P. Ottaviano (2014): "Market Size, Competition, and the Product Mix of Exporters," American Economic Review, 104(2), $495-536$.

Moore, T. G. (2002): China in the World Market: Chinese Industry and International Sources of Reform in the Post-Mao Era, Cambridge University Press.

Qiu, L. D. And W. Zhou (2013): "Multiproduct Firms and Scope Adjustment in Globalization," Journal of International Economics, 91(1), 142-153.

YANG, Y. (1999): "China's Textile and Clothing Exports: Changing International Comparative Advantage and Its Policy Implications," Working Paper, Australian National University. 